\title{
Use of social media in Free State tourism small, medium and micro enterprises to widen business networks for competitiveness
}

\begin{tabular}{|c|c|}
\hline \multicolumn{2}{|c|}{$\begin{array}{l}\text { Authors: } \\
\text { Lentswe Mosweunyane }^{1} \\
\text { Patient Rambe }^{1} \\
\text { Dennis Dzansi }\end{array}$} \\
\hline \multicolumn{2}{|c|}{$\begin{array}{l}\text { Affiliations: } \\
{ }^{1} \text { Department of Business } \\
\text { Support Studies (BSS), } \\
\text { Central University of } \\
\text { Technology, Bloemfontein, } \\
\text { South Africa }\end{array}$} \\
\hline \multicolumn{2}{|c|}{$\begin{array}{l}\text { Corresponding author: } \\
\text { Lentswe Mosweunyane, } \\
\text { Imosweuny@cut.ac.za }\end{array}$} \\
\hline \multicolumn{2}{|c|}{$\begin{array}{l}\text { Dates: } \\
\text { Received: } 16 \text { Aug. } 2018 \\
\text { Accepted: } 16 \text { Jan. } 2019 \\
\text { Published: } 29 \text { Apr. } 2019\end{array}$} \\
\hline \multicolumn{2}{|c|}{$\begin{array}{l}\text { How to cite this article: } \\
\text { Mosweunyane, L., Rambe, P. } \\
\text { \& Dzansi, D., 2019, 'Use of } \\
\text { social media in Free State } \\
\text { tourism small, medium and } \\
\text { micro enterprises to } \\
\text { widen business networks } \\
\text { for competitiveness', South } \\
\text { African Journal of Economic } \\
\text { and Management Sciences } \\
\text { 22(1), a2780. https://doi.org/ } \\
\text { 10.4102/sajems.v22i1.2780 }\end{array}$} \\
\hline \multicolumn{2}{|c|}{$\begin{array}{l}\text { Copyright: } \\
\text { (C) 2019. The Authors. } \\
\text { Licensee: AOSIS. This v } \\
\text { is licensed under the } \\
\text { Creative Commons } \\
\text { Attribution License. }\end{array}$} \\
\hline \multicolumn{2}{|l|}{ Read online: } \\
\hline 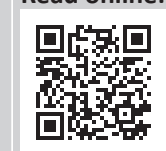 & $\begin{array}{l}\text { Scan this QR } \\
\text { code with your } \\
\text { smart phone or } \\
\text { mobile device } \\
\text { to read online. }\end{array}$ \\
\hline
\end{tabular}

Background: While the proliferation of social media is hailed for increasing corporate business networking and competitiveness, this claim has not been sufficiently tested in tourism small, medium and micro enterprises (SMMEs) in African emerging economies where traditional communication modes tend to dominate.

Setting: This study investigates the use of social media in tourism SMMEs to widen their business networks to increase competitiveness.

Aim: This study contributes to the debate on business networking among stakeholders within the tourism sector.

Methods: To close the research gap, the current study employed stakeholder theory and survey data of 123 hospitality SMMEs to explore the influence of social media utilisation for business networking with stakeholders and its effect on business competitiveness.

Results: Findings showed that the majority of tourism SMMEs used social media technologies to retain their customer base, solicit feedback from customers, assert their dominance in the market, maintain contact between their co-workers and share information. Moreover, the findings indicate that there is a significant positive relationship between social media business networking and competitiveness of these firms. The study recommended that tourism SMMEs should create a policy framework for comprehensive stakeholder engagement that serves the interests of all individuals.

Conclusion: To increase the competitiveness of such firms, SMMEs should incorporate social media into their formal internal and external information strategy.

Keywords: Social media; networking; stakeholder; small, medium and micro enterprises; business competitiveness; SMMEs.

\section{Introduction}

Social media networking, which denotes the use of social media to engage with a business' internal and external stakeholders, seems to have attracted the attention of large corporations that have resource endowments to generate a large customer base and shape the public image of their brands. The established body of literature focuses on large corporations' use of social media for advancing business competitiveness (Aimiuwu 2012; Pereira Medina 2014). However, the emerging phenomenon of small, medium and micro enterprises (SMMEs) in developing economies using social media to advance their competitiveness has been under explored in literature (Meske \& Stieglitz 2013). For the purpose of this study, business competitiveness describes the ability of a business to regularly and successfully yield products or services that meet the requirements of an open market and enable the business to stay operational by gaining market share (Sipa, Gorzen-Mitka \& Skibiński 2015). Yet the need to understand the influence of social media business networking on the competitiveness of SMMEs cannot be ignored as it promotes and markets business brands (Ananda, Hernández-García \& Lamberti 2015) and develops new products and improves customer service for business (Arca 2012). Antoldi, Cerrato and Depperu (2011) suggest that a network indicates a social structure that includes a set of relationships between different individuals. The popularity of social media networking as a field of study seems to stem from the important role it plays in binding and bringing individuals and businesses together. In the context of this study, this network includes employers and employees 
(internal network) and customers, suppliers, competitors, regulators and surrounding communities (external network). Furthermore, social media are platforms that can smoothe the construction of social interactions among these different networks and provide opportunities for them to share suggestions, concerns, interests and activities through connections (Oyza \& Edwin 2015).

Tourism SMMEs are small businesses that employ fewer than 200 employees and offer tourism products or services to consumers (Pierce 2011) in emerging economies. However, SMMEs' lack of a competitive plan to improve the sustainability of their business operations and their failure to utilise the increasing importance of social media as interaction and communication tools undermine their competitiveness. Dahnil et al. (2014) concur that SMMEs are known to have limitation and acceptance barriers in utilising emerging technologies such as social media for networking. One of the major limitations to SMMEs' use of technologies stems from the poverty of resources within these businesses (Ghobakhloo et al. 2012). Despite this failure by tourism SMMEs, social media networking gives businesses a voice and a way to communicate with stakeholders (Ndekwa \& Katunzi 2016). It personalises the brand and assists businesses to spread their message in a relaxed and conversational way (Ndekwa \& Katunzi 2016). Hence, technological innovation is a significant component in today's knowledge economy. Ludmila and Stanislava (2015) state that social media technologies (SMTs) are important resources of competitiveness for businesses; thus the use of social media may play an important role in the competitiveness of SMMEs. Lim (2010) observes that the tourism sector is slowly gaining momentum with regard to technology adoption and SMMEs are unwilling to adopt these technological advances. Besides, the tourism sector also fears social media because they think that it could be detrimental to employee productivity or fear that social media has the potential to harm the business' reputation. Social media may have negative implications on employee productivity in the workplace (Hettiarachchi 2017; Mohamed et al. 2017). Furthermore, Zeng and Gerritsen (2014) add that the tourism sector is faced with the possibility that social media, if not managed properly, can be a source of negative influence from dissatisfied customers. Therefore, the industry has not taken advantage of the power of social media and they have not incorporated it in their marketing initiatives. Lim (2010) posits that social media is an alternative platform for tourism SMMEs to enrich their knowledge and extend their network of connection. Therefore, these SMMEs should take advantage of these emerging technologies to expand and influence both their internal and external network to gain competitiveness. In view of the above, this study addresses the following research questions:

1. To what extent do tourism SMMEs utilise social media to broaden their business networks (i.e. supply chain networks)?

2. What impact does SMMEs' utilisation of social media technologies have on business competitiveness?

\section{Background to the study}

Small, medium and micro enterprises play a substantial part in the creation of employment and are considered one of the key drivers of economic growth (Brand, Du Preez \& Schutte 2007; Dahnil et al. 2014). This assertion also includes tourism SMMEs.

Tourism seems to be a growing sector in South Africa to address the nation's social challenges of overcoming poverty, unemployment and inequality. Xasa (2017) concurs that the South African tourism economy is one of the best performing economic sectors in South Africa, outperforming many of the traditional South African sectors, and also creating permanent jobs as well as stimulating job creation. This is because tourism is labour intensive (Aynalem, Birhanu \& Tesefay 2016; Meyer \& Meyer 2015). In many developing and transition economies, tourism has emerged as the dominant tool for economic growth. This is supported by Mihalic (2014) who states that most developing economies conceive tourism development as their chance for economic development. The same applies to the Free State province of South Africa. Tourism SMMEs in the Free State are mostly bed and breakfast establishments and guesthouses. Some of these SMMEs are informal establishments that have turned their homes into a business. This micro focus might be the reason these businesses may not be using social media for networking with their business stakeholders.

\section{The desirability of business networking for small, medium and micro enterprises}

The globalisation and growing competitiveness of the tourism market demand greater flexibility within tourism businesses (Borodako \& Kožić 2016). Borodako (2011) affirms that in a tourism sector dominated by SMMEs, flexibility may be realised by support for a range of stakeholders internal and external to the business. Even so, the literature concerning ways of cooperation in the tourism business is rather uncommon (Borodako \& Kožić 2016). Nevertheless, internal and external networking within this sector is important for its competitiveness. Sosa, Roy and Bautista (2015) concur that social media business networks are central in demonstrating what the business stands for and this indicates that they are involving their internal and external networks. The social media business networks have evolved to a point that they now allow people to use them to generate sales and increase the competitiveness of enterprises. Tourism SMMEs should also utilise this prominent phenomenon in order to increase their competitiveness.

Networking is often an informal way of attaining a mutual goal, but its time frame is not usually limited (Borodako \& Kožić 2016). According to Borodako and Kožić (2016) the external drive of networking is created by the business environment, in particular globalisation, rapid technological changes, climate change, humanity's increasing mobility, and escalating competition between tourism destinations and businesses. The internal drive for cooperation networks 
is mostly dependent on resources, the need for a cooperating partner in the market is especially prevalent among SMMEs. This is especially predominant in the tourism sector as customers are globalised and therefore the competition is high. Hence, De la Garza and Contreras (2016) hypothesise that networks are an option for competitiveness enhancement, giving basis to multiple interactions, internal and external, for the benefit of all stakeholders. Tourism SMMEs' use of SMTs as a channel of communication to different networks can ease the interaction described above.

The plethora of SMTs are among the opportunities available to businesses in their bid to connect with existing and prospective customers and other stakeholders. Moreover, Oyza and Edwin (2015) advance that relationship building and interactions are the main motives for embracing of SMTs by individuals. However, businesses can also take advantage of this phenomenon by using it to build relationships with their stakeholders. Oyza and Edwin (2015) concur that businesses leverage the universal usage of these technologies and see them as platforms on which to interact directly with existing and new stakeholders. Also, Floyd (2015) suggests that the use of emerging technologies to promote modern communication enhances interactivity and significance within the business environment both internally and externally. Thus, social media connects people globally irrespective of differences and geographical boundaries (Sawyer 2011). In the same breath, businesses can also use social media to link them with different players within the organisation (internal) as well as outside the organisation (external) and thus affect competitiveness.

Therefore, from the above assertions, the authors postulate that SMTs may facilitate the internal and external networks between a business and its stakeholders for business competitiveness.

\section{Social media and business networks}

Esse, Szántó and Wimmer (2012:99) postulate that the domination of internal performance indicators has been disappearing and a growing emphasis on external factors has emerged. Based on this, SMMEs should also use external networks to increase performance without neglecting internal networks. Thus, tourism SMMEs may utilise SMTs as a channel to engage both internal and external networks. Furthermore, Walters, Bhattacharjya and Chapman (2011) affirm that there is increasing evidence for the suggestion that shifting customer markets are increasing the significance of flexibility for business success and that SMTs are easing the development of business models that embody this characteristic. This means SMTs have an indirect influence on competitiveness of businesses as it serves as a channel to internal and especially external networks. Hence SMTs give businesses an opportunity to engage with their different stakeholders wherever they are. Walters, Bhattacharjya and Chapman (2011) concur that the critical part is how businesses use the capacity that technology offers to generate opportunities for richer communication and global reach.

Therefore, a well facilitated cooperation of tourism SMMEs with its internal and external networks will likely lead to competitiveness. In concurrence, De la Garza and Contreras (2016) posit that networks are a choice for competitiveness enhancement, being a source of several relationships, internal as well as external, which will define the relationships' strength to the benefit of all stakeholders, especially in matters of innovation. If tourism SMMEs use SMTs to engage in networking, more businesses will reach a wider stakeholder base thus achieving competitiveness. Hence, Curley and Noormohamed (2014) speculate that there is much excitement about social media platforms and their possible effect on global marketing. Tourism SMMEs should also take advantage of this opportunity by adopting these emerging technologies to be able to compete with other larger businesses by networking with their various stakeholders. In relation to this assertion, Curley and Noormohamed (2014) advise that social media marketing is becoming a richer vehicle to allow businesses to network with various stakeholders. This is because of the view that in today's connected world, people are not just observing the shifting environment; they are active and willingly devoting more time online (Sedereviciute \& Valentini 2011). This assertion is especially critical for tourism SMMEs who compete internationally as well. Sedereviciute and Valentini (2011) posit that the most significant opportunity of networking through social media is the prospect of communicating directly with stakeholders without the mediation of other entities. Businesses are gradually becoming keen to use social media for business purposes, in particular for communication, marketing and recruitment. Likewise, tourism SMMEs' customers, stakeholders and regulators are able to communicate and share information in inexpensive ways from anywhere around the world. As such, tourism SMMEs' underutilisation of social media can contribute to the limited effectiveness of their competitive strategy.

\section{Business networks and competitiveness}

Competitiveness is crucial for a business's sustenance as it displays a business's ability to innovate and fulfil customers' changing needs thus giving a positive signal to business networks. Competitiveness is the ability to generate and sustain superior performance relative to competitors (Centenaro \& Laimer 2016:67). Lakhal et al. (1999) state that business networking to become internationally competitive forms the base of strategic decisions in many businesses. This can be true especially for tourism SMMEs who compete internationally. Tourism SMMEs use informal networks to collect information on a mix of issues. Ludmila and Stanislava (2015) concur that networks are strategic for development and expansion of new ideas and innovations and thus the attainment of competitiveness. Networks provide access to 
resources, knowledge and skills required for the development and exploitation of new business opportunities (Ludmila \& Stanislava 2015). Through a business's access to stakeholders, whether internal or external, it can acquire the resources essential for increasing its competitiveness.

Centenaro and Laimer (2016:67) affirm that competitiveness is associated with the business' capability to compete in the market and gain superior performance to its competitors. Consequently, competitiveness is related to a number of factors in a given market, which is part of the interdependence between companies (Centenaro \& Laimer 2016). Equally, for businesses, a competitive factor (e.g. cooperative relationships through networking) becomes viable for a business that is measured by their performance. In the tourism sector, relationships and cooperation of different stakeholders can be crucial for increasing sustainability, competitiveness or even survival in terms of destination competitiveness, but also at the level of individual tourism businesses (Perić, Đurkin \& Lamot 2014). Moreover, Centenaro and Laimer (2016:67) postulate that network relationships can then provide an increase in the business' competitiveness and, as a consequence, vary its performance in relation to those businesses that do not network with others. Ludmila and Stanislava (2015) concur that using business networking has resulted in crafting solid relationships in firms, thus building a stronger network and gaining competitiveness for SMMEs. Accordingly, cooperative relationships are a determining factor of business competitiveness, enabling the business to engage in cooperation for superior performance in relation to its competitors that operate in isolation (Centenaro \& Laimer 2016).

In view of the above, it is imperative that tourism SMMEs should formalise their business networking internally and externally in order to become competitive. In accordance with this, Ludmila and Stanislava (2015) affirm that networking appears to have a positive effect on growth and it is a foundation of benefits for businesses. The simplest way to achieve this is through the utilisation of SMTs as a channel to access different stakeholders in this network.

This article has presented literature on how tourism SMMEs may employ social media to increase their business networks to gain competitiveness. The next section discusses the theory underpinning the study.

\section{Stakeholder theory}

Stakeholder theory is a useful perspective for addressing important issues in business (Harrison, Freeman \& Abreu 2015). These authors further maintain that this theory is effective in that stakeholders that are well taken care of tend to reciprocate with a positive attitude towards the business. Stakeholder theory involves attending to the interests and well-being of all business stakeholders (Harrison, Bosse \& Phillips 2010). Hence, this theory's purpose is to create value not only for business owners but for stakeholders as well. Thus, stakeholder theory is drawn on in this article to show how it could be relevant to understanding tourism SMMEs' stakeholders within social media environments.

Since its emergence, social media has reached into the business world and taken over (Pietarinen 2014). It offers easy, interactive and cost-efficient possibilities to interact with various stakeholders (Krumay \& Geyer 2016). It is evident from practice to suggest that social media is a suitable way to establish stakeholder involvement within a business. Pietarinen (2014) states that many businesses have difficulties grasping what social media is and why it has become such a phenomenon, although they aim to benefit from it through developing strategic goals and reaching specific stakeholder groups to become competitive.

Competitiveness is the core issue of strategic management in which stakeholder theory is rooted (Wu 2012). Wu (2012) further states that a business' competitiveness is achieved by its strategic choice. Therefore, the competitiveness of the business can be achieved through the integration of social media and stakeholder theory.

The next section discusses the methodology followed in the research.

\section{Research design}

This article adopted a quantitative descriptive research method. The researchers conducted a thorough literature review and developed a Likert scale based questionnaire. The Free State Department of Economic Development, Tourism and Environmental Affairs estimated that there were approximately 600 tourism SMMEs in the Free State province. Using a sample size calculator at a confidence level of $95 \%$, the researchers established a target sample of 234 tourism SMME owners or managers. They employed probability sampling to select a simple random sample to ensure the probability of generalising to the study population (Maree 2013).

\section{Data collection}

A closed-ended structured questionnaire was developed based on reviewed literature and research questions used to collect data. Through the process of constructing the instrument, different phases were followed and a statistical expert's advice was adhered to. Only 123 questionnaires were completed correctly, representing a 53\% response rate. A response rate of $50 \%$ is adequate for analysis (Bryman \& Bell 2011) as there is growing evidence that achieving a good response rate may be difficult when surveying a small business population. The study also considered ethical issues such as informed consent and privacy of the participants. With the help of research assistants, it took approximately 2 months to collect data. The authors also administered the data collection instrument to the SMME owners and managers at times convenient to them to avoid disturbances of their routine business. 


\section{Data analysis}

Data from collected questionnaires was coded and captured into Excel and exported into Statistical Package for the Social Sciences (SPSS) version 21 for detailed analysis. The study employed descriptive statistics such as frequency tables to establish the extent of use of SMTs for external and internal networking. Inferential statistics, in particular correlation analysis and regression analysis, were employed to examine the relationships between competitiveness and stakeholder variables (which comprise internal and external networks and stakeholder variables relating to SMTs).

\section{Reliability of data}

A preliminary check ensured reliability of the variables used in the analysis. The variables constructed for analysis are external networking, internal networking, suppliers, competitors and investors, regulators and competitiveness. Cronbach's alpha coefficient calculations determined whether the variables are reliable. The coefficients are presented in Table 1.

A Cronbach's alpha value above 0.6 indicates a reliable variable (Rahimnia \& Raude 2013). Table 1 shows that all the constructed variables have a Cronbach's alpha coefficient that is above 0.6 which means that these variables are reliable and further statistical analysis could be conducted.

\section{Validity of data}

To address the objectives of this study, factor analysis was instrumental in determining the validity of the constructs used in the analysis. The variables constructed for further analysis are external networking and internal networking. The results in Tables 4 and 5 indicate that the latent factor (factor loading) for the items measuring each construct were predominantly above 0.6 . Rahn (2018) considers this valid to measure the constructs in question for a factor analysis.

\section{Presentation and discussion of findings Demographic data}

Table 2 indicates that $62.6 \%$ of respondents were managers and only $17 \%$ were owners. The interpretation of this could mean owners prefer to hire managers rather than run their own business. About $63 \%$ of respondents were between 21 and 40 years old, showing that the majority were in the economically active population. The majority

TABLE 1: Cronbach's alpha's reliability test.

\begin{tabular}{lcc}
\hline Constructed variables & Cronbach's alpha & Number of items \\
\hline External networking & 0.881 & 8 \\
Internal networking & 0.864 & 5 \\
Suppliers & 0.939 & 3 \\
Competitors and investors & 0.915 & 5 \\
Regulators & 0.881 & 4 \\
Competitiveness & 0.693 & 2 \\
\hline
\end{tabular}

of respondents $(65.6 \%)$ studied up to tertiary education. Also, the number of years in business as illustrated in Table 2 indicates that the majority $(78.3 \%)$ of businesses have been in operation between 1 to 10 years. This indicates that the tourism SMMEs in the province have survived long enough.

The majority $(82.9 \%)$ of respondents indicated that they use SMTs while only $17.1 \%$ do not use it. The willingness of tourism SMME owners and managers to adopt SMTs resonates with Meske and Stieglitz's (2013) revelation that these technologies are significant to the routine operations of tourism SMMEs. Moreover, Table 3 shows that $67.5 \%$ (22.8\% advanced and $44.7 \%$ intermediary) of respondents were knowledgeable about SMTs. It further illustrates that several respondents (15.4\%) used these technologies despite being beginners or novices. This indicates the importance of these emerging technologies and respondents' willingness to use them for business operations.

Table 3 shows that almost half of respondents (46.7\%) use SMTs to attract new customers while only $10.7 \%$ of respondents use them to network. This attitude is confirmed by Cesaroni and Consoli (2015) who postulate that the popularity of SMTs among SMMEs disturbingly coexists with the failure to utilise them effectively. Consistent with this finding, only $30.1 \%$ of respondents consider social media important for their business. Despite $46.7 \%$ of respondents considering SMTs important for business, only $15.4 \%$ use them to communicate with stakeholders. The findings indicate that irrespective of the majority $(82.9 \%)$ of owners and managers using social media, most do not see social media as important for business operations. Clearly, there is a lack of stakeholder approach as evidenced from this finding. Siti-Nibiha and Saad (2015) concur with this statement that the stakeholder engagement practice in tourism is selective in nature.

TABLE 2: Sample demographics.

\begin{tabular}{llcc}
\hline Variables & Category & Frequency & $\%$ \\
\hline Role in the business & Owner & 21 & 17.1 \\
& Manager & 59 & 48.0 \\
& Owner/Manager & 18 & 14.6 \\
& Other & 25 & 20.3 \\
Age & $21-30$ years & 39 & 32.0 \\
& $31-40$ years & 38 & 31.1 \\
Education & $41-50$ years & 32 & 26.2 \\
& Above 50 & 13 & 10.7 \\
Hears business has & High school & 42 & 34.4 \\
been in operation & Tertiary & 60 & 49.2 \\
& Postgraduate & 20 & 16.4 \\
& $1-5$ years & 40 & 33.3 \\
& $6-10$ years & 54 & 45.0 \\
& $11-15$ years & 15 & 12.5 \\
& $16-20$ years & 2 & 1.7 \\
Number of employees & Over 20 years & 9 & 7.5 \\
in the business & None & 8 & 6.5 \\
& $1-5$ & 63 & 51.2 \\
& $6-9$ & 29 & 23.6 \\
& $10+$ & 23 & 18.7 \\
\hline
\end{tabular}




\section{Business external networking}

Table 4 presents frequencies and descriptive statistics for statements related to businesses' use of SMTs for external networking. The frequency distribution shows that $67.5 \%$ of the businesses respond to questions and comments

TABLE 3: Status and utilisation of social media technologies.

\begin{tabular}{|c|c|c|c|}
\hline Variables & Categories & Frequency & Percentage \\
\hline \multirow{2}{*}{$\begin{array}{l}\text { The business } \\
\text { uses social media } \\
\text { technologies. }\end{array}$} & Yes & 102 & 82.9 \\
\hline & No & 21 & 17.1 \\
\hline \multirow{4}{*}{$\begin{array}{l}\text { How do you rate your } \\
\text { social media } \\
\text { knowledge? }\end{array}$} & No knowledge & 21 & 17.1 \\
\hline & Beginner/Novice & 19 & 15.4 \\
\hline & Intermediary & 55 & 44.7 \\
\hline & Advanced & 28 & 22.8 \\
\hline \multirow{4}{*}{$\begin{array}{l}\text { How often does your } \\
\text { business use social } \\
\text { media technologies? }\end{array}$} & Once/more a day & 35 & 28.5 \\
\hline & Once/more a week & 28 & 22.8 \\
\hline & Once/more every month & 42 & 34.1 \\
\hline & Never & 18 & 14.6 \\
\hline \multirow{7}{*}{$\begin{array}{l}\text { What are the reasons } \\
\text { for your business's use } \\
\text { of social media } \\
\text { technologies? }\end{array}$} & Do not use social media & 19 & 15.6 \\
\hline & Marketing products/service & 21 & 17.2 \\
\hline & Build credibility & 12 & 9.8 \\
\hline & Attracting new customers & 57 & 46.7 \\
\hline & Network & 6 & 4.9 \\
\hline & Listen to customers & 4 & 3.3 \\
\hline & Provide feedback & 3 & 2.5 \\
\hline \multirow{4}{*}{$\begin{array}{l}\text { To what extent } \\
\text { does your business } \\
\text { consider social media } \\
\text { technologies important } \\
\text { for its operations? }\end{array}$} & Not at all & 15 & 12.2 \\
\hline & To a little extent & 18 & 14.6 \\
\hline & Neutral & 53 & 43.1 \\
\hline & Moderate extent & 37 & 30.1 \\
\hline \multirow{4}{*}{$\begin{array}{l}\text { How do you rate your } \\
\text { staff's knowledge of } \\
\text { social media? }\end{array}$} & Novice & 35 & 28.5 \\
\hline & Beginner & 20 & 16.3 \\
\hline & Intermediary & 56 & 45.5 \\
\hline & Advanced & 12 & 9.8 \\
\hline \multirow{4}{*}{$\begin{array}{l}\text { Who are your business } \\
\text { trying to reach through } \\
\text { social media } \\
\text { technologies? }\end{array}$} & Existing customers & 81 & 71.1 \\
\hline & Prospective customers & 21 & 18.4 \\
\hline & Suppliers & 11 & 9.6 \\
\hline & Competitors & 1 & 0.9 \\
\hline \multirow{5}{*}{$\begin{array}{l}\text { Which methods do } \\
\text { the business use to } \\
\text { communicate with } \\
\text { stakeholders? }\end{array}$} & None & 8 & 6.5 \\
\hline & Telephone & 22 & 17.9 \\
\hline & E-mail & 70 & 56.9 \\
\hline & Letter & 4 & 3.3 \\
\hline & Social media technologies & 19 & 15.4 \\
\hline
\end{tabular}

from customers and potential customers posed on SMTs. In support, Leung et al. (2013) posit that Facebook offers an alternative web-based tool for tourism SMMEs to provide information, promote products and services, and respond to customer inquiries. Leung et al. (2013) add that a probable reason for this finding is that practitioners usually regard SMTs as a marketing and information distribution channel. Table 4 further illustrates that $62.6 \%$ of respondents agree that their businesses are significantly broadening customers' awareness of their products using SMTs. These statistics illustrate many tourism SMMEs use SMTs to network externally with their stakeholders especially customers. Such external networking with external stakeholders will provide SMMEs with a wide range of benefits in additional areas, including consumer marketing (Bughin, Chui \& Manyika 2012). Table 4 further indicates that about $57.9 \%$ of the businesses use SMTs intensively to retain existing customers. The interpretation is that communication is a key to business success as it assists businesses in communicating with existing stakeholders. Baruah (2012) concurs that SMTs are good for customer interaction, customer feedback and customer support, and new business contacts are necessary for networking purposes.

The frequency distribution shows that $49.6 \%$ of the businesses use Facebook discussion forums to increase their dominance in the market. About $44.3 \%$ of the businesses collaborate with customers on WhatsApp to interact and improve their brand. Moreover, $41.5 \%$ of the businesses use Google+ to connect with and increase their market share. Although the usage of SMTs could increase the market share as indicated in the findings, the percentage is not satisfactory bearing in mind the popularity of SMTs among the customers and potential customers. A further $25.2 \%$ of the businesses employ LinkedIn to connect their product range to potential customers, whereas $18.7 \%$ of the businesses encourage customers to follow their personnel on Twitter. The above findings show that social media bridges the space among different business stakeholders through external networking (Baruah 2012).

TABLE 4: External networking.

\begin{tabular}{|c|c|c|c|c|c|c|c|c|c|c|}
\hline \multirow[t]{2}{*}{ External networking } & & \multicolumn{6}{|c|}{ Frequency distribution } & \multicolumn{2}{|c|}{ Descriptive } & \multirow{2}{*}{$\begin{array}{l}\text { Latent factor: } \\
\text { Factor loading }\end{array}$} \\
\hline & & $\begin{array}{l}\text { Strongly } \\
\text { disagree }\end{array}$ & Disagree & Neutral & Agree & $\begin{array}{l}\text { Strongly } \\
\text { agree }\end{array}$ & $\begin{array}{l}\% \text { agree and } \\
\text { strongly agree }\end{array}$ & Mean & $\begin{array}{l}\text { Standard } \\
\text { deviation }\end{array}$ & \\
\hline \multirow{2}{*}{$\begin{array}{l}\text { The business uses Facebook discussion forums to } \\
\text { increase its dominance in the market }\end{array}$} & $n$ & 11 & 26 & 25 & 36 & 25 & 49.6 & 3.31 & 1.27 & 0.80 \\
\hline & $\%$ & $8.9 \%$ & $21.1 \%$ & $20.3 \%$ & $29.3 \%$ & $20.3 \%$ & & & & \\
\hline \multirow{2}{*}{$\begin{array}{l}\text { The business encourages customers to follow its } \\
\text { personnel on Twitter. }\end{array}$} & $n$ & 16 & 59 & 25 & 12 & 11 & 18.7 & 2.55 & 1.13 & 0.62 \\
\hline & $\%$ & $13.0 \%$ & $48.0 \%$ & $20.3 \%$ & $9.8 \%$ & $8.9 \%$ & & & & \\
\hline \multirow{2}{*}{$\begin{array}{l}\text { The business employs Linkedin to connect its product } \\
\text { range to potential customers. }\end{array}$} & $n$ & 14 & 64 & 14 & 18 & 13 & 25.2 & 2.63 & 1.20 & 0.58 \\
\hline & $\%$ & $11.4 \%$ & $52.0 \%$ & $11.4 \%$ & $14.6 \%$ & $10.6 \%$ & & & & \\
\hline \multirow{2}{*}{$\begin{array}{l}\text { The business uses Google+ to connect with stakeholders } \\
\text { and increase its market share. }\end{array}$} & $n$ & 7 & 44 & 21 & 35 & 16 & 41.5 & 3.10 & 1.18 & 0.58 \\
\hline & $\%$ & $5.7 \%$ & $35.8 \%$ & $17.1 \%$ & $28.5 \%$ & $13.0 \%$ & & & & \\
\hline \multirow{2}{*}{$\begin{array}{l}\text { The business collaborates with customers on WhatsApp } \\
\text { to interact and improve its brand. }\end{array}$} & $n$ & 10 & 42 & 16 & 38 & 16 & 44.3 & 3.05 & 1.24 & 0.66 \\
\hline & $\%$ & $8.2 \%$ & $34.4 \%$ & $13.1 \%$ & $31.1 \%$ & $13.1 \%$ & & & & \\
\hline \multirow{2}{*}{$\begin{array}{l}\text { The business uses social media technologies intensively } \\
\text { to retain existing customers. }\end{array}$} & $n$ & 4 & 28 & 19 & 41 & 29 & 57.9 & 3.54 & 1.17 & 0.87 \\
\hline & $\%$ & $3.3 \%$ & $23.1 \%$ & $15.7 \%$ & $33.9 \%$ & $24.0 \%$ & & & & \\
\hline $\begin{array}{l}\text { The business uses social media technologies to increase } \\
\text { the base of prospective customers. }\end{array}$ & $\%$ & $4.1 \%$ & $17.9 \%$ & $11.4 \%$ & $39.8 \%$ & $26.8 \%$ & & & & \\
\hline \multirow{2}{*}{$\begin{array}{l}\text { The business is significantly broadening customers' } \\
\text { awareness of its products using social media technologies. }\end{array}$} & $n$ & 5 & 21 & 20 & 45 & 32 & 62.6 & 3.64 & 1.17 & 0.87 \\
\hline & $\%$ & $4.1 \%$ & $17.1 \%$ & $16.3 \%$ & $36.6 \%$ & $26.0 \%$ & & & & \\
\hline
\end{tabular}




\begin{tabular}{|c|c|c|c|c|c|c|c|c|c|c|}
\hline \multirow[t]{2}{*}{ Internal networking } & & \multicolumn{6}{|c|}{ Frequency distribution } & \multicolumn{2}{|c|}{ Descriptive } & \multirow{2}{*}{$\begin{array}{l}\text { Latent factor - } \\
\text { Factor loading }\end{array}$} \\
\hline & & $\begin{array}{l}\text { Strongly } \\
\text { disagree }\end{array}$ & Disagree & Neutral & Agree & $\begin{array}{l}\text { Strongly } \\
\text { agree }\end{array}$ & $\begin{array}{l}\% \text { agree and } \\
\text { strongly agree }\end{array}$ & Mean & $\begin{array}{l}\text { Standard } \\
\text { deviation }\end{array}$ & \\
\hline $\begin{array}{l}\text { The business responds to questions and comments } \\
\text { from customers and potential customers posed on } \\
\text { social media technologies. }\end{array}$ & $n$ & 8 & 22 & 10 & 47 & 36 & 67.5 & 3.66 & 1.25 & 0.87 \\
\hline \multirow{2}{*}{$\begin{array}{l}\text { The business's personnel are actively present in social } \\
\text { media technologies for marketing purposes. }\end{array}$} & $n$ & 11 & 39 & 27 & 24 & 22 & 37.4 & 3.06 & 1.26 & 0.82 \\
\hline & $\%$ & $8.9 \%$ & $31.7 \%$ & $22.0 \%$ & $19.5 \%$ & $17.9 \%$ & & & & \\
\hline \multirow{2}{*}{$\begin{array}{l}\text { The business's employees use social media to contact } \\
\text { co-workers when they are unreachable by other means. }\end{array}$} & $n$ & 11 & 28 & 18 & 42 & 24 & 53.7 & 3.33 & 1.27 & 0.82 \\
\hline & $\%$ & $8.9 \%$ & $22.8 \%$ & $14.6 \%$ & $34.1 \%$ & $19.5 \%$ & & & & \\
\hline \multirow{2}{*}{$\begin{array}{l}\text { The business's employees maintain contact with other } \\
\text { people in the organisation through social media. }\end{array}$} & $n$ & 10 & 22 & 29 & 43 & 19 & 50.4 & 3.32 & 1.18 & 0.88 \\
\hline & $\%$ & $8.1 \%$ & $17.9 \%$ & $23.6 \%$ & $35.0 \%$ & $15.4 \%$ & & & & \\
\hline \multirow{2}{*}{$\begin{array}{l}\text { The business's employees are free to engage with } \\
\text { customers on SMTs. }\end{array}$} & $n$ & 13 & 22 & 31 & 41 & 16 & 46.3 & 3.20 & 1.19 & 0.63 \\
\hline & $\%$ & $10.6 \%$ & $17.9 \%$ & $25.2 \%$ & $33.3 \%$ & $13.0 \%$ & & & & \\
\hline
\end{tabular}

\section{Business internal networking}

Table 5 presents frequencies and descriptive statistics for statements related to business use of SMTs for internal networking.

About $53.7 \%$ of the businesses agree that their employees use social media to contact co-workers when they are unreachable by other means. Employees need each other to be productive and clearly SMTs are useful in connecting them when unreachable. In addition, just over half (50.4\%) of the businesses agree that their employees maintain contact with other people in the organisation through social media. This can help employees to share information that will help in production processes. Chin et al. (2015) concur that an internal employee network not only promotes camaraderie but it also promotes information sharing which will lead to productivity. Kasavana, Nusair and Teodosic (2010) further agree and propose that SMTs utilised among employees constitute a collaboration of organisational intelligence, optimisation of employee talents, facilitation of communication, and shared insights related to the work environmental situation. It must, therefore, be stressed that social media impact on the nature and quality of employees' job performance (Mohamed et al. 2017), thus aiding competitiveness of the business.

About $37.4 \%$ of the businesses surveyed agree that their personnel are actively present in SMTs for marketing purposes. Contrary to the results for external networking on Table 4, these findings indicate that tourism SMMEs in the study area do not adequately utilise social media to communicate internally.

\section{Social media utilisation to broaden business networks}

In order to address this objective, the mean percentages of the statements of external and internal networking, suppliers and competitors and investors in relation to SMTs were calculated. Table 6 presents the means and percentages of networked stakeholders.

The percentage of internal networking is $66.2 \%$, which is a high percentage indicating that most businesses use SMTs
TABLE 6: Mean percentages of networking, suppliers, competitors and investors.

\begin{tabular}{lcc}
\hline Variables & Mean & $\mathbf{\%}$ \\
\hline External networking & 25.51 & 63.8 \\
Internal networking & 16.56 & 66.2 \\
Suppliers & 7.86 & 52.4 \\
Competitors and investors & 14.53 & 58.1 \\
\hline
\end{tabular}

for internal networking. This finding is substantiated by Meske and Stieglitz's (2013) survey on German SMMEs, which affirms SMMEs' use of SMTs to support collaboration among employees and to improve knowledge management. The percentage of external networking is $63.8 \%$, indicating that most of the businesses use SMTs for external networking. However, Table 3 indicates that tourism businesses network mainly with customers. This is perhaps because tourism SMMEs perceive customers as the most important stakeholders for their business. In support of this view, Popp and Woratschek (2017) affirm that to manage relationships with customers is a common driver of large enterprises and SMMEs. However, Harrison and Wicks (2013) affirm that SMMEs should network with all stakeholder groups such as customers, suppliers, competitors and investors rather than focusing on just one.

Furthermore, the percentage for competitors and investors is above half $(58.1 \%)$ while for suppliers it is $52.4 \%$, which indicates that about half of the businesses use SMTs to communicate with their suppliers. Similarly, these findings illustrate that these businesses are indeed using SMTs to generally network with their stakeholders. Moreover, FossoWamba and Carter (2014) concur that social media tools can assist with improved communication and collaboration between the business and its stakeholders. However, those tourism SMMEs (a sizeable number) that do not use social media to network with their stakeholders stand to miss these advantages. This is based on the assertion that social media is important and can improve the competitiveness of any business (Gomez, Chalmeta \& Sosa-Varela 2012; Lutz \& Hoffmann 2013). Furthermore, Gomez et al. (2012) advance that through social media channels, businesses can create and promote two-way communication processes where they can include and engage stakeholders in discussions that can profit both parties. 
TABLE 7: Regression analysis (competitiveness versus stakeholder variables relating to SMTs).

\begin{tabular}{lcccc}
\hline $\begin{array}{l}\text { Dependent variable: } \\
\text { Competitiveness }\end{array}$ & \multicolumn{2}{c}{ Coefficients } & T statistic & $p$ \\
\cline { 2 - 3 } & Unstandardised & Standardised & & \\
\hline Intercept & 4.912 & - & 10.400 & 0.000 \\
External networking & 0.018 & 0.088 & 0.662 & 0.509 \\
Internal networking* & 0.088 & 0.300 & 2.195 & 0.030 \\
Competitors and investors & -0.019 & -0.071 & -0.458 & 0.648 \\
Regulators & -0.011 & -0.032 & -0.215 & 0.830 \\
Adjusted R-square & 0.247 & - & - & - \\
\hline
\end{tabular}

*, significant variables

\section{The influence of stakeholder networking on competitiveness}

Table 7 indicates that only the $\mathrm{p}$-values for internal networking are below 0.1 which means that the businesses' use of SMTs for internal networking has a significant impact on competitiveness. Moreover, the coefficient of the variable internal networking is 0.088 , which is a positive impact on competitiveness. The positive coefficient means that an increase in the business's use of SMTs for internal networking will lead to an improvement in the competitiveness of the business. In support of this finding, Bulankulama, Khatibi and Shokri's (2014) study on the effect of the utilisation of social media on competitive advantage affirms that employee interaction and exchange of knowledge and information will increase tourism SMMEs' competitiveness. In concurrence, Mohamed et al. (2017) establish that social media has become a common channel of communication for employees to join forces, integrate and share information with colleagues within the business. Furthermore, Gomez et al. (2012) claim that utilising social media to network offers countless advantages for a business competitiveness.

The networking of different stakeholders within the tourism sector can assist SMMEs in encouraging collective promotion of tourism products and overcoming issues that are the result of competition (Pjerotić, Rađenović \& Tripković-Marković 2016). When it comes to managing competitiveness of tourism, the role of networking, especially externally, should be highlighted.

\section{Recommendations}

Although internal networking had significant positive influence on competitiveness, there is a need to balance the internal and external networking of these tourism SMMEs and stakeholders. Besides, if tourism SMMEs improve their networking with all their stakeholders and do not focus mainly on customers it will be of benefit not only to their businesses but to all the stakeholders as well, and will further increase competitiveness through spillover effects, such as building of social trust, creation of entrepreneurial social capital and building social cohesion.

The results show that the tourism SMMEs' external networking is focused predominantly on customers rather than other stakeholders. In view of this, there is a need for more inclusive and robust stakeholder engagement and business management should therefore identify all relevant stakeholders. The engagement policy framework would assist most tourism SMMEs to cease focusing on customers solely and target other stakeholders. Tourism SMMEs can also benefit from clearly articulating their needs, expectations and desires to their stakeholders through the creation of an inclusive stakeholder engagement policy framework that serves their interests and reconciles perceived conflicts of interest among stakeholders.

Given the importance of tourism in the South African economy and the proliferation of SMTs in recent years, this study sought to establish interventions for increasing the competitiveness of tourism SMMEs in such a highly competitive complex globalised sector. Sharing of technological knowledge, information, processes and systems through networking can further improve the competitiveness of the SMMEs. Most scholars generally concur that the use of social media is important to the competitiveness of tourism SMMEs (Aspasia \& Ourania 2014; Baruah 2012; Királová \& Pavlíčeka 2015; Surugiu \& Surugiu 2015). In view of the above, there is a need for tourism SMME managers and owners to ensure their business's competitiveness through networking with business stakeholders. Therefore, for competitiveness to occur, stakeholder management needs to be part of the tourism SMMEs' strategy. To increase the competitiveness of such firms, the formal internal and external information strategy of these businesses can be integrated into social media to improve their competitiveness. Networking relationships with stakeholders are an important foundation for competitiveness of businesses.

\section{Conclusion and implications for future research}

This study examined the utilisation of social media to broaden business networks and its impact on competitiveness. The utilisation of social media on an ad hoc and informal basis by tourism SMMEs in the study area indicates that there are no formal policies on the use of these technologies. Perhaps future studies should investigate the formalisation of SMTs within SMMEs. Additionally, the findings indicated that there was over-concentration of the use of social media on customers. Perhaps, future studies may also need to do a comparison study on competitiveness of SMMEs adopting social media for one purpose and those adopting SMTs for wider use.

\section{Acknowledgements}

This research article would not be possible without the guidance of my mentors who are also co-authors of the article. Above all, I would also like to thank my family for the love and support throughout writing of this article.

\section{Competing interests}

The authors declare that they have no financial or personal relationships that may have inappropriately influenced them in writing this article. 


\section{Authors' contribution}

L.M. was responsible for the conception or design of the work as well as the data collection, data analysis, interpretation, and drafting of the article. P.R. did a critical revision of the article and D.D. contributed towards the revision and the final approval of the version published.

\section{References}

Aimiuwu, E., 2012, 'Building a competitive edge through social media', Proceedings of the Conference on Information Systems Applied Research, New Orleans, LA 1-4 November.

Ananda, A., Hernández García, Á. \& Lamberti, L., 2015, 'Social media marketing in Italian luxury fashion', 5th Annual International Workshop on Luxury Retail, Operations and Supply Chain Management, Milán, Italia, 25-27 May, pp. 1-17.

Antoldi, F., Cerrato, D. \& Depperu, D., 2011, Export consortia in developing countries' successful management of cooperation among SMEs, Springer, Heidelberg.

Arca, C., 2012, Social Media Marketing benefits for businesses: Why and how should every business create and develop its Social Media Sites? Master of International Marketing, Aalborg University, Aalborg.

Aspasia, V. \& Ourania, O., 2014, 'Social Media adoption and managers' perceptions', International Journal on Strategic Innovative Marketing 1, 61-73.

Aynalem, S., Birhanu, K. \& Tesefay, S., 2016, 'Employment opportunities and challenges in tourism and hospitality sectors', Journal of Tourism Hospitality 5(6), 257. https:// doi.org/10.4172/2167-0269.1000257

Baruah, T.D., 2012, 'Effectiveness of Social Media as a tool of communication and its potential for technology enabled connections: A micro-level study', Internationa Journal of Scientific and Research Publications 2(5), 1-10.

Bhattacharjya, W.D. \& Chapman, J., 2011, 'Drivers of falling interaction costs in global business networks', Competitiveness Review: An International Business Journal 21(1), 9-28. https://doi.org/10.1108/10595421111106201

Borodako, K., 2011, 'Cooperation of small and medium-sized tourism enterprises (SMTEs) with tourism stakeholders in the Małopolska region - Top management perspective approach', Tourism \& Management Studies 7, 24-32

Borodako, K. \& Kožić, I., 2016, 'Cooperation patterns in the tourism business: The case of Poland', Prague Economic Papers 25(2), 160-174. https://doi.org/10.18267/j. pep. 552

Brand, R.P., Du Preez, N. \& Schutter, C.S., 2007, 'A business framework to network small South African enterprises for sustainability', South African Journal of Industrial Engineering 18(2), 187-201.

Bryman, A. \& Bell, E., 2011, Business research methods, Oxford University Press, New York.

Bughin, J., Chui, M. \& Manyika, J., 2012, 'Capturing business value with social technologies', McKinsey Quarterly, viewed 26 April 2018, from http://www. mckinsey.com/industries/high-tech/our-insights/capturing-business-value-withmckinsey.com/industrial-technologies
social

Bulankulama, S.W., Khatibi, A. \& Shokri, T.S., 2014, 'The effect of utilization of social media for competitive advantage in Sri Lankan Hotel industry', International Journal for Innovation Education and Research 2(12), 127-132.

Centenaro, A. \& Laimer, C.G., 2016, 'Cooperative relationships and competitiveness in supermarket sector', Review of Business Management 19(63), 65-81. https://doi. org/10.7819/rbgn.v0i0.3070

Cesaroni, F.M. \& Consoli, D., 2015, 'Are small businesses really able to take advantage of social media?', The Electronic Journal of Knowledge Management 13(4), 257-268.

Chin, C.P., Evans, N., Choo, R.K. \& Tan, F.B., 2015, 'What influences employees to use enterprise social networks? A socio-technical perspective', PACIS 2015 Proceedings, Paper 54, Singapore, 6-9 July.

Curley, C.B. \& Noormohamed, N.A., 2014, 'Social media marketing effects on corporate social responsibility', Journal of Business \& Economics Research 12(1), 61-66. https://doi.org/10.19030/jber.v12i1.8379

Dahnil, M.I., Marzuki, K.M., Langgat, J. \& Fabeil, N.F., 2014, 'Factors influencing SMEs adoption of social media marketing', Procedia - Social and Behavioral Sciences 148, 119-126. https://doi.org/10.1016/j.sbspro.2014.07.025

De la Garza, J.A. \& Contreras, T.J., 2016, 'Business networks in tourism and service sectors for competitiveness improvement in Ciudad Juarez, Chihuahua, Mexico. A case study: central park Hermanos Escobar and surrounding SME's', Cuadernos de Turismo 37, 543-545.

Esse, B., Szántó, R. \& Wimmer, A., 2012, 'Business relationships and relationships with stakeholders - Perception of Hungarian executives', The IMP Journal 6(2), 98-108.

Floyd, A., 2015, Modern communication and intranets: Successful internal communications, viewed 04 September 2017, from https://www.linkedin.com/ pulse/modern-communication-intranets-successful-internal-amy-nitzana-mamane

Fosso-Wamba, S. \& Carter, L., 2014, 'Social media tools adoption and use by SMEs: An empirical study', Journal of End User and Organizational Computing 26(1), 1-16. https://doi.org/10.4018/joeuc.2014040101
Ghobakhloo, M., Hong, T., Sabouri, M. \& Zulkifli, N., 2012, 'Strategies for successful information technology adoption in small and medium-sized enterprises', Information 3, 36-67. https://doi.org/10.3390/info3010036

Gomez, L.M., Chalmeta, R. \& Sosa-Varela, J.C., 2012, 'Usage and importance of social media for corporate communication and stakeholder dialogue', Proceedings of AMS World Marketing Congress: Cultural Perspectives in Marketing, 56-57, Atlanta, GA, 28 August-1 September.

Harrison, J.S., Bosse, D.A. \& Phillips, R.A., 2010, 'Managing for stakeholders, stakeholder utility functions and competitive advantage', Strategic Management Journal 31, 58-74. https://doi.org/10.1002/smj.801

Harrison, J.S. Freeman, R.E. \& Abreu, M., 2015, 'Stakeholder theory as an ethical approach to effective management: Applying the theory to multiple contexts', Review of Business Management 17(55), 858-869. https://doi.org/10.7819/rbgn. v17i55.2647

Harrison, J.S. \& Wicks, A.C., 2013, 'Stakeholder theory, value, and firm performance', Business Ethics Quarterly 23(1), 97-124. https://doi.org/10.5840/beq20132314

Hettiarachchi, H., 2015, 'Social media and employee productivity: An extended bibliography. A working paper'. https//doi.org/10.13140/RG.2.2.29408.58884

Kasavana, M.L., Nusair, K. \& Teodosic, K., 2010, 'Online social networking: Redefining the human web', Journal of Hospitality and Tourism Technology 1(1), 68-82. https://doi.org/10.1108/17579881011023025

Királ'ová, A. \& Pavlíčeka, A., 2015. 'Development of social media strategies in tourism destination', Social and Behavioral Sciences 175, 358-366. https://doi.org/ 10.1016/j.sbspro.2015.01.1211

Krumay, B. \& Geyer, S., 2016, 'The role of social media for stakeholder involvement: A literature review', 29th Bled eConference Digital Economy, Bled, Slovenia, 19-22 June.

Lakhal, S., Martel, A., Oral, M. \& Montreuil, B., 1999, 'Network companies and competitiveness: A framework for analysis', European Journal of Operational Research118, 278-294. https://doi.org/10.1016/S0377-2217(99)00026-0

Leung, D., Law, R., Van Hoof, H. \& Buhalis, D., 2013, 'Social media in tourism and hospitality: A literature review', Journal of Travel \& Tourism Marketing 30(1-2), hospitality: A literature review', Journal of Travel \& To

Lim, W., 2010, 'The effects of social media networks in the hospitality industry', UNLV theses, dissertations, Professional Papers, and Capstones, 693, viewed 04 March 2018, from http://digitalscholarship.unlv.edu/thesesdissertations/693

Ludmila, S. \& Stanislava, G., 2015, 'The application of business network approach for small and medium enterprises (SME) with regard to their buying behavior', Journal of Competitiveness 7(3), 62-74. https://doi.org/10.7441/joc.2015.03.05

Lutz, C. \& Hoffmann, A.C., 2013, 'The impact of social media on stakeholder engagement', Conference Paper June: ICA Preconference 'Governance through Communication: Stakeholder Engagement, Dialogue, and Corporate Socia Responsibility', At Edinburgh. https://doi.org/10.13140/2.1.2934.9442

Maree, K., 2013, First steps in research, Van Schaik Publishers, Pretoria.

Meyer, D.F. \& Meyer, N., 2015, 'The role and impact of tourism on local economic development: A comparative study', African Journal for Physical Health Education, Recreation and Dance (AJPHERD) 21(1:1), 197-214.

Meske, C. \& Stieglitz, S., 2013, 'Adoption and use of social media in small and mediumsized enterprises', in F. Harmsen \& H. Proper (eds.), Practice-driven research on enterprise transformation, pp. 61-75, Lecture Notes in Business Information Processing: Vol. 151, Springer, Berlin.

Mihalic, T., 2014, 'Tourism and economic development issues', in R. Sharpley \& D. Telfer, J. (eds.), Tourism and development. concepts and issues, 2nd edn., pp. 77-117, Channel View Publications, Toronto.

Mohamed, S., Sidek, S., Izharrudin, Z., Kudus, N., \& Hassan, A., 2017, 'Social media impact on employee productivity at the workplace: A review', Asian Journal of Information Technology 16(1), 32-37.

Ndekwa, A.G. \& Katunzi, T.M., 2016, 'Small and medium tourist enterprises and social media adoption: Empirical evidence from Tanzanian Tourism Sector', Internationa Journal of Business and Management 11(4), 71-80. https://doi.org/10.5539/ijbm. viln 4 p71

Oyza, I. \& Edwin, A.M., 2015, 'Effectiveness of social media networks as a strategic tool for organizational marketing management', Journal of Internet Banking and Commerce 21(S2), 19 pages.

Pereira, A. \& Medina, G., 2014, 'Digital social media: An interactive technology incorporated as a competitive advantage for business', International Journal of Interactive Mobile Technologies 8(2), 23-27.

Perić, M., Đurkin, J. \& Lamot, I., 2014, Importance of stakeholder management in tourism project: Case study of the Istra Inspirit project, University of Rijeka, Croatia.

Pierce, A., 2011, Small and medium-sized enterprises in tourism industries, viewed 01 December 2016, from https://www.ic.gc.ca/eic/site/061.nsf/vwapj/ SBFProfileProfilFPE

Pietarinen, S., 2014, 'Corporate branding in social media - Stakeholder involvement in value co-creation: A case study', Master's thesis, Aalto University, Finland.

Pjerotić, L.J., Rađenović, M. \& Tripković-Marković, A., 2016, 'Stakeholder cooperation in Montenegrin tourism destinations - Current state and constraints', Economics and Organization 13(1), 87-100.

Popp, B. \& Woratschek, H., 2017, 'Consumers' relationships with brands and brand communities - The multifaceted roles of identification and satisfaction', Journal of Retailing and Consumer Services 35, 46-56. https://doi.org/10.1016/j. jretconser.2016.11.006

Rahimnia, F. \& Hassanzadeh, J.F., 2013, 'The impact of website content dimension and e-trust on e-marketing effectiveness: The case of Iranian commercial saffron corporations', Information \& Management 50(5), 240-247. 
Rahn, M., 2018, Factor analysis: A short introduction, viewed 04 March 2018, from https://www.theanalysisfactor.com/factor-analysis-1-introduction/

Sawyer, R., 2011, The impact of new social media on intercultural adaptation, Senior Honors Projects. Paper 242, viewed 23 January 2018, from http://digitalcommons. uri.edu/srhonorsprog/242

Sedereviciute, K. \& Valentini, C., 2011, 'Towards a more holistic stakeholder analysis approach. Mapping known and undiscovered stakeholders from social media', International Journal of Strategic Communication 5(4), 221-239. https://doi.org/ $10.1080 / 1553118 X .2011 .592170$

Sipa, M., Gorzeń-Mitka, I. \& Skibiński, A., 2015, 'Determinants of competitiveness of small enterprises: Polish perspective', Procedia Economics and Finance 27 445-453. https://doi.org/10.1016/S2212-5671(15)01019-9

Siti-Nabiha, A.K. \& Saad, N.H., 2015, 'Tourism planning and stakeholders' engagements: The case of Penang Island', Problems and Perspectives in Management 13(2), 269-276.
Sosa, J., Roy, A. \& Bautista, A., 2015, 'Micro, small and medium enterprises and social networks in tourism industry in Manzanillo, Colima, Mexico', International Journal of Business and Management III(1), 90-105. https://doi.org/10.20472/BM.2015. 3.1.006

Surugiu, M.R. \& Surugiu, C., 2015, 'Heritage tourism entrepreneurship and social media: Opportunities and challenges', Social and Behavioural Sciences 188 74-81. https://doi.org/10.1016/j.sbspro.2015.03.340

Wu, M., 2013, 'Towards a stakeholder perspective on competitive advantage', International Journal of Business Management 8(4), 20-29. https://doi.org/ 10.5539/ijbm.v8n4p20

Xasa, T., 2017, 'Final draft - National tourism sector strategy', Staatskoerant 40827, 53-97.

Zeng, B. \& Gerristsen, R., 2014, 'What do we know about social media in tourism? A review', Tourism Management Perspectives 10, 27-36. https://doi.org/10.1016/ j.tmp.2014.01.001 